of the subject? Yes, but is there ever, in reality, absolute liberty? I think not."

Lord Rothschild is not, from what he said on Wednesday this week, an instinctive supporter of "big research". The proton accelerator being built near Chicago on 6,800 acres of prairie, and already equipped with three artificial lakes for fishermen, two herds of buffalo and an office in Chicago for the recruitment of black workers, had already cost $£ 100$ million and was no doubt a forerunner for an instrument that would cost ten or a hundred times as much. Such a "gadget ... . with or without the lakes and buffaloes" was outside the British purse, "but in our own modest way we have similar intentions". Lord Rothschild went on to refer to the proposal that the Science Research Council should finance a high flux beam reactor at a cost of $£^{\prime} 22$ million and he wanted "the scientific establishment" to ask whether it might not be better to spend the money on Titian's Death of Actaeon (which would still leave room for another nine equally expensive paintings), twenty miles of motorway, four hospitals, 300 adventure playgrounds, four prisons, 200,000 television sets, two Jumbo jets or 4,500 houses.

How should people decide what projects in applied research should be supported? Quality of research and individual creativity are no less important than elsewhere but there are also questions to be asked of economists, those who value clean air and clean country and even those who worry about law and order. "These deep and fundamental national questions cannot be decided by scientists alone" and in this sense Britain shares with other nations an anachronism. He was not seeking a regime in which scientists would be told meticulously what to do but he did protest against the "pedestalization of science" and the way in which the admiration of the British for pure science spilled over into the making of decisions on applied science. "Have we not got 4.6 Nobel prizewinners per ten million of our people in comparison with America's 3.3?" Scientists might have a part to play in studying problems such as urban conglomeration, agricultural needs and drug addiction, just as do other people---sociologists, engineers, lawyers, economists, accountants, mathematicians and administrators. Unhappliy, in Lord Rothschild's view, the government was still too wedded to the idea that in circumstances like this it was necessary only to find good scientists "and let them get on with the job". He blamed not so much the people themselves as their willingness to invoke the outmoded Haldane principle, with its justification of scientific freedom or. rather, laissez faire.
Lord Rothschild complained that one of the consequences of the Haldane principle had been to polarize society into scientists and the rest, with detrimental effects on government research and development and with the result that there had emerged autonomous bodies, the research councils, which were accountable to Parliament but "not accountable to anybody else in spite of their names which include such bizarre words as agricultural, medical and natural environment. Is it not strange that though the taxpayer pays for these bodies, he has no say in what they do?"

Lord Rothschild went on to say that "we scientists are neither black, selfish, thoughtless and unpatriotic; nor are we white, selfless, unthoughtful patriots. Like virtually everyone else, we are grey curates' eggs." And scientists are conservative and were hanging on to the Haldane principle, as interpreted, without recognizing how much damage it had done in polarizing society and the civil service.

What is to be done? Lord Rothschild was optimistic about the problems of the civil service, which will be solved "during the next five or so years". Nor is he worried about basic research, an activity in its own right even if it does consume between 13 and 17 per cent of the British government's expenditure on

\section{Scientific Administrutors}

LORD ROTHSCHILD said this week that within five years there would be a free interchange of scientists and administrators within the civil service. The present reluctance to have such interchange is, according to Lord Rothschild, not due to administrative, financial or geographical difficulties but because a belief pervades the civil service that administrators cannot play an important role in scientific policy making and that scientists make bad administrators. The truth, according to Lord Rothschild, lies somewhere in between.

$\mathrm{Mr}$ William McCall, general secretary of the Institution of Professional Civil Servants, who has been agitating for such an interchange for some time, said this week that he was delighted with this aspect of Lord Rothschild's lecture. $\mathrm{Mr}$ McCall added that the foundations of a better arrangement for interchange will be laid soon and that he was determined that the system should be in full operation within five years. research. But he did ask that applied research should be linked with practical objectives, that research workers should not be solely responsible for formulating these objectives nor even for deciding whether "the objective requires research for its achievement. He should not decide that the research should be done, assuming it is necessary. $\mathrm{He}$ should not decide when to stop. Nor should he decide to change the objective in midstream, however desirable it may seem to him to do so." Rather, it is for scientists to do the research and to help out when they can.

This is where the doctrine of the customer and the contractor comes in Lord Rothschild has no strong opinion, to tell from his lecture on Wednesday, about the kinds of basic research that should be carried out. "What, however. I do object to is virtually all medical, agricultural and environmental research being controlled autonomously by scientists and to a lesser extent mathematicians and engineers, with concomitant downgrading of the research commissioned by government departments and, with a few exceptions such as Bell Telephone Laboratories, by industry. We must, I believe, oppose the deliberate creation and nurture of this kind of scientific elite-the autonomous haves and the departmental or industrial have-nots."

By his own admission, Lord Rothschild seems well aware that his philosophy "is anathema to very many scientists, particularly of course to some of those intimately connected with our research council system". Haldane has been beatified by the scientific establishment and Lord Rothschild was particularly scornful, in his address on Wednesday, of Sir Harold Himsworth's defence of the research council system in his book The Development and Organisation of Scientific Knowledge (Heinemann, 1970). Is it possible that scientists are so corrupt that they will cook the books when working for government departments? Can ministers in the 1970s actually suppress facts? Is it sensible to fear that venality in government departments can survive in the face of honesty from abroad?

But what is it all for? Lord Rothschild's complaint is that the scientific community is clinging to outdated concepts. He considers that there is no such thing as science policy but that it is important to develop policies on pollution, ocean resources, food supplies and so on. But "science as a whole is not an activity to be carried on in isolation. It must be part of society's integrated effort to make the world a better place." And it is for "democratic society itself and its elected representatives" to give scientists their marching orders. 